\title{
The Influencing Factors Analysis of China's Equipment Manufacturing Industry in the Global Value Chain Position
}

\author{
Yan $\mathrm{Li}^{1, \mathrm{a}}$ and Yijun Yuan ${ }^{2, \mathrm{~b}}$ \\ ${ }^{1}$ Faculty of Management and Economics, Dalian University of Technology. Transportation \\ Management School, Dalian Maritime University, Dalian, China \\ ${ }^{2}$ Faculty of Management and Economics, Dalian University of Technology, Dalian, China \\ alilyyanfire@163.com, byjyuan@dlut.edu.cn
} Keywords: Global value chain (GVC); Trade in valued; Influencing factors; Equipment
manufacturing

\begin{abstract}
Equipment manufacturing industry can provide the basic machinery production activities and equipment for the national economy and national defense construction. It is a core component of the manufacturing sector and it has an important role in promoting economic growth and industrialization process. Therefore, analysis of equipment manufacturing industry influence factors is crucial. In this paper, we use multiple linear regression method to analyze from the five aspects of technical level, factor endowments, industry size, institutional factors and the degree of opening. The results showed that the level of technology and the degree of opening up have a significant positive effect to upgrade the status of China's manufacturing equipment; While, the influence of the industry size, factor endowments and relevant institutional factors to raise the status is not significant, Wherein there are still some negative effect in improving the status of the global value chain the endowment of China's equipment manufacturing industry.
\end{abstract}

\section{Introduction}

Equipment manufacturing industry can provide the basic machinery production activities and equipment for the national economy and national defense construction.

In recent years, China's equipment manufacturing industry and export trade continued to flourish. After the first trade surplus in 2004, the trade import of Chinese equipment manufacturing industry amounted to $\$ 820$ billion and the trade exports amounted to $\$ 11300$ billion in 2013 , the proportion were $42 \%$ and $51 \%$. After the reform and opening up, the most important factors that affect China's equipment manufacturing industry should be the global manufacturing vertical specialization (or global value chains) development. Attracting foreign investment has become the largest players in the global value chain. However, under the background of global value chain division, international division level gradually penetrated from the product to the production chain. Because there is a serious problem of double counting, the traditional trade statistics with a total value of merchandise has been unable to objectively reflect the real situation of international trade. With the development and continuous improvement of inter-State Input-Output Database (ICIO) and the Global Trade Analysis database (GTAP), it is possible to use the input-output tables imported and domestic investment coefficient matrix to distinguish foreign and domestic value added value of the full value of total exports. The trade statistics statistical framework of the added value of for the analysis of international trade issues under the new international division system offers a new perspective.

\section{An Empirical Analysis of the Factors Related to China Equipment Manufacturing Industry in the Global Value Chain Specialization of Position}

The Factors. The factors that affect the position related to equipment manufacturing industry in the global value chain specialization are mainly as follows: technology, factor endowment, industrial scale, institutional factors, and openness. 
The Technology of Equipment Manufachuring Industry. To improve the position of a country in the global value chain specialiazaion, not only the deepening level of the global value chain specialization and the improvement of product added value need China equipment manufacturing industry improve its technology,bur also the acquisition of dynamic profit in the global value chain specialization. The technology means the development of the science and technology,especially the development of information and transportation technologies.Multinational Manufacturing will bring the cost of communication,transportation and management, which makes the equipment manufacturing industry encounter problems when fostering transnational production network.However,the extensive use of network and the development of container transportation lower the service cost in the distributed production and clear the obstacle in the global value chain specialization. The technology includes the assemblage and application of technical knowledge,the latter belonging to the aspect of administration.Enterprises can also realize the improvement of the position in the global value chain specialization themselves by R\&D and accumulation. The technical ability may be acquired from the global value chain specialization.Participating in the technology transfer in the global value chain specialization is mainly from the angle of information and knowledge to expand.The situation are divided into 3 aspects:First,buyers participate in suppliers' R\&D;Second,buyers transfer information about the product specification to suppliers. Third,buyers provide design information and specific quality standard to suppliers. The knowledge transfer in the global value chain specialization needs the drive of the enterprises which are leading the industry.And the leading enterprises'support to the upgrading value chain is in accordance with its demand.For domestic equipment manufacturing industry,improving the ability of absorption is the essential.

The Factor Endowment in the Equipment Manufachuring Industry. The factor endowment means the quantitative ratio of nature resources,labour force and capital at one time or in one industry.According to the traditional factor endowment theory,the industries which are relative capital - concentrated exported technology-intensive products. Therefore, the quantities of the factor is the important elements that influence the industry technology advantage and the benefits of global value chain specialization. What's more,the factor endowment will realize dynamic advantage transformation with the accumulation and transfer of the factors.China has the comparative advantage of labor resources which is not easy to transfer.But China can accumulate the captital to change the restruction of the factors so as to realize the combination of labour advantage and capital advantage in the equipment manufacturing industry.China equipment manufacturing industries have bring the capital that is lacked at home and the increase of administration and technology via the participation in the global value chain specialization. Therefore, it optimizes the factor endowment advantage of China equipment manufacturing industries.

The Industrial Scale of Equipment Manufacturing Industries. The industrial scale is the core factor to facilitate one country to realize global industrial distribution.It concerns the precedence of China equipment manufacturing industries in the global value chain specialization.And this factor leads to Lock-in Effect in the specialization of all the countries. That is to say,once the situation of the global value chain specialization has formed,it is hard to change.Therefore,the industrial scale has an essential impact on China equipment manufacturing industry in the global value chain specialization .It provides basic economical foundation for the global value chain specialization.To gain the effects of scale economy is the imoportant power and foundation for the participation of China equipment manufacturing industry in the global value chain specialization.Scale economy is also the effective factor to promote the upgrading of China equipment manufacturing industry in the global value chain. This article adopt the total output of equipment manufacturing industry and import and export trade which are related to the scale economy of China equipment manufacturing industry to measure.

Related Institutional Factors. Institutional factors are mainly about the degree of liberalization related to trade and investment.Trade liberalization is beneficial to lower the transaction costs of enterprises.Investment liberalization create advantages for the free international flow of the capital.Only the trade and investment liberaliazation are developed can realize the global value chain specialization.So the institutional factors drive the global value chain specialization. Free and open 
market and institutional factors contribute to the build of export-led industrial for the host country.At the same time,the enterprises can be brought to the production and procurement system of multinational companies more easily, which makes these enterprises have more chances to improve its technical level and participate in the global value chain specialization better.Open markets can be measured by Effective Tariff Rate,Foreign Trade Conditions and Degree of Dependance upon Foreign Trade.Their impact on one country's position of manufacturing industries in the global value chain specialization is mainly manifested through the comparative advantages mechanism in international division.

Openess. In the context of global value chain,the upgrading of equipment manufacturing industry is affeced by the external factors more easily for late developing countries. The impact includes two aspects:import and export trade and FDI.On the one hand,the development of international trade makes late developing countries can import scarce production elements from countries with advanced technology.For example:Importing advanced technical equipments from foreign countries can improve the productivity of domestic equipment manufacturing industry.And through the Export Guidance Strategy these countries can accept part of foreign enterprises transfered.What is more,relying on the progressive of the manufacturing product export ladder is helpful to realize the upgrading of equipment manufacturing industry.On the other hand,the foreign capital afflux to the host country is usually accompanied by technology and knowledge spillover to some extent.Enterprises in the host countries innovate through the expand and adaption of technology, which can accelerate the technical transformation of the company and improve the competitiveness in order to upgrade the industry.

Variable Selection and Model Constructing. Variable Selection. According the factors, we would like to adopt the following 7 elements as independent variables to research on the GVC index of China equipment manufacturing industry.The elements are:X1 is the proportion of patent applications; $\mathrm{X} 2$ is the output of China equipment manufacturing industry; $\mathrm{X} 3$ is the value of import and export of China equipment manufacturing industry; $\mathrm{X} 4$ is the average level of tariff;X5 is the proportion of foreign-funded enterprise export; $\mathrm{X} 6$ is the ratio between total assets and employees in China equipment manufacturing industry;X7 is Ratio of Dependenceon Export of China equipment manufacturing industry.

Model Constructing. Adopt the method of Multiple Regression and construct the model as follows:

$$
\mathrm{Y}=\mathrm{C}+\mathrm{C}_{1} \mathrm{X}_{1}+\mathrm{C}_{2} \mathrm{X}_{2}+\mathrm{C}_{3} \mathrm{X}_{3}+\mathrm{C}_{4} \mathrm{X}_{4}+\mathrm{C}_{5} \mathrm{X}_{5}+\mathrm{C}_{6} \mathrm{X}_{6}+\mathrm{C}_{7} \mathrm{X}_{7}
$$

According to the constructed regression model,we can get regressive equation through Stationarity Tests,Significance Tests and Tests for Heteroscedasticity.

$$
\mathrm{Y}=-0.348+0.09 \mathrm{X}_{1}-0.003 \mathrm{X}_{6}+0.314 * \mathrm{X}_{7}
$$

\section{The Research Conclusion}

According to the analysis of the model, we can get the following basic conclusions:

Level of Technology. According to the regression results, we can find that the higher the proportion of the total amount of application for a patent in the world in China, the higher the GVC status index of equipment manufacturing industry in China and the more obvious of the effects which can achieve to $8.98 \%$. What is more, the empirical and expected results are the same. In a word, if the level of technology is improved, it would be benefit for equipment manufacturing industry in China to shift from low-end to high-end in the division of global value chain,also the position of equipment manufacturing industry in China in the division of global value chain would be promoted.

The Scale of the Equipment Manufacturing Industry. This article selected two indicators about the equipment manufacturing industry in China: Total value of out-put and Value of import and export. According to the empirical results, the two indicators have no significant effects on the position of equipment manufacturing industry in China in the division of global value chain.In a global context, there is no significant relationship between the position and scale in the equipment manufacturing industry when we are measuring the division of global value chain. 
The Factor Endowment of the Equipment Manufacturing Industry. This article chose industry structure to react to the factor endowment of the equipment manufacturing industry, so the indicator is the ratio of total assets and the employees. According to the empirical results, there is a negative correlation relationship between the indicator and the explained variable. Also the effect on the position of division of global value chain is $0.3 \%$. We can see the factor of human capital in the study of many scholars. The calculation results from Liangqun Qi who has studied about the human capital of equipment manufacturing industry in Liaoning province show that human capital play a positive role in upgrading equipment manufacturing industry in Liaoning province.There is a big gap in the quality of human capital between China and developed countries. So we need to explore more ways towards the introduction of talents and retain talents,especially in the aspects of the equipment manufacturing industry. The introduction of high-quality talentd have advantages to the development of equipment manufacturing industry in China, then we can improve our position in the division of global value chain.

Relevant Institutional Factors. The institution contains extremely rich content. Considering the availability of panel data,this article selected the factors of average tariff level and the terms of foreign trade as the institution variable of the equipment manufacturing industry in China. In the aspects of the terms of foreign trade, we chose the ratio of total exports and enterprises with foreign investment.According to the empirical results, we can find that the two indicators have no significant effects on improving the position of equipment manufacturing industry in China in the division of global value chain. Although tariff reduction can make it more reasonable for the division between countries and maximize the national interest, in the aspects of the acquisitions of added value and dynamic interests in the division of global value chain, it can not pass the test of significance. So the institutional factors have little effect on the stability of international status in the equipment manufacturing industry.

Degree of Openness. Export dependence shows the degree of external expansion which is important to measure the degree of openness, also it can reflect how one industry is dependent on the demand of external market. According to regression analysis results, Explain and be explained variables are positively correlated, and the effect is relatively significant. It shows if the proportion of exports to GDP is higher and the degree of the division of global value chain is deeper in China, it would be more beneficial to acquire the added value and dynamic interests. Though the amount of total resources in China is great, the amount of the average resource is small. So when we are opening up to the outsides, we need to draw on advantages and avoid disadvantages. On the basis of the use of global resources, we need to take advantage of the huge domestic market and labor force so that we can get lasting motive force of development. Then the position of equipment manufacturing industry in China in the division of global value chain would be improved.

\section{Acknowledgements}

The paper is subsidized by Basic scientific research fund project of central university (3132016037).

\section{References}

[1] Zhang Yonghua. Global manufacturing value chain and its dynamic evolution [J], World Economy,2015,06: 61-71. (In Chinese).

[2] Liu Zhibiao. Country Value Chain Reconstruction: Reflections on development mode of Chinese manufacturing transformation [J], World Economy And Politics, 2011,04: 1-14. (In Chinese).

[3] Wang Fei. Guomeng Ke.The position of China's textile and garment industry in the global value chain [J], International Trade Issues, 2014,12: 14-24. (In Chinese).

[4] Qian Feng. China's terms of trade continued to deteriorate? - Based on estimating the kind of change [J], Management World, 2010, 07:18-29. (In Chinese). 
[5] Lin Guijun, Hewu.The status and upgrade trends of China's equipment manufacturing industry in global value chains [J], International Trade Issues, 2015, 04: 3-15. (In Chinese).

[6] Shi BingZhan.Chinese export products in the international division status - based on product specialization within the viewing angle [J] ,World Economic Research, 2010 (1): 56-62 + 88-89. (In Chinese).

[7] Tang Bi. Analysis of the status and factors affecting Chinese high-tech industry value chain [J] Economic Perspectives, 2012,10: 65-70. (In Chinese).

[8] Qiu Bin. An Empirical Study of participation in global production networks to enhance the impact of our manufacturing value chain - based on the export of complexity [J], Chinese industrial economy, 2012,01: 57-67. (In Chinese).

[9] Gong Sanle. Enterprises to upgrade performance, Performance Evaluation and Impact Factors within the global value chain - A Case Study of IT Industrial Clusters [J] reform and strategy, 2011,07: 178-181.

[10]Li Feng. International Division Position in Global Value Chain: The Meaning and Influence Factors [J], International Economics and Trade Research, 2015,09: 31-42. (In Chinese). 